\title{
Foto Perjuangan Muslimah Bercadar Karya Hesti Rika Di Cnnindonesia.Com dengan Analisis Semiotika Roland Barthes
}

\author{
Denny Aprianto \\ dennyays@gmail.com \\ Tantan Hermansah \\ tantan.hermansah@uinjkt.ac.id \\ UIN Jakarta
}

\begin{abstract}
Abstrak
Adanya pemberitaan tentang terorisme dengan ilustrasi bergambar wanita bercadar pada berbagai media di Indonesia telah menghasilkan stereotif pengguna cadar itu sendiri. Pengguna cadar kerap kali diasosiasikan kepada kelompok intoleran, berpaham radikal, hingga istri seorang teroris. Hesti Rika, fotografer cnnindonesia.com mencoba memberi perspektif lain tentang pengguna cadar melalui karya fotonya. Melalui foto-foto yang diambil dari berbagai momen, Hesti seperti menyampaikan pesan agar kita lebih obyektif melihat subyek pengguna cadar ini. Fotografi sudah lama menjadi medium yang cukup efisien untuk menyampaikan pesan. Melalui tiga tahap pemaknaan ala Barthes, pesan pada foto-foto Hesti yang ditampilkan pada halaman website cnnindonesia.com bisa ditafsirkan dengan melihat tanda atau simbol yang ditemukan dalam foto tersebut. Dari hasil analisis semiotika Bhartes, bisa diambil kesimpulan bahwa dalam karya fotografi Hesti Rika, terdapat beragam makna, yaitu makna aktivitas pengguna cadar yang sama seperti masyarakat pada umumnya. Akan tetapi pada foto tersebut juga terkandung makna perjuangan para pengguna cadar menghapus stigma negatif itu dengan cara mengintegrasikan diri pada lingkungan sosialnya.

Kata Kunci: Fotografi, Semiotika, Cadar, Stigma
\end{abstract}

Permalink/DOI: http://doi.org/10.15408/jsj.v2i2.18919

\section{Pendahuluan}

Beragam cara digunakan individu untuk mengekspresikan identitas keagamaan yang dimilikinya. ${ }^{1}$ Mulai dari ritual

1 Buwaizhi, Rini Iswari, Asma Luthfi. Ekspresi Identitas Keacehan Dalam Interaksi Sosial Di Tengah Lingkungan Non-Syariat Islam (Studi Kasus pada Komunitas Ikatan Pelajar Aceh

Semarang). http://journal.unnes.ac.id/sju/inde x.php/solidarity. Juga bisa dilihat dalam, Oki seperti datang ke tempat ibadah, mengunjungi makam leluhur, dan sebagainya. Ekspresi keagamaan juga dapat dilihat dari cara pemikiran

Rahadianto Sutopo. Beragam Islam, Beragam Ekspresi: Islam Indonesia dalam Praktik. MASYARAKAT, Jurnal Sosiologi, Vol. 15, No. 2, Juli 2010: 85-97. 
seseorang2. Selain itu, ekspresi keagamaan juga dapat direpresentasikan melalui gaya hidup seperti cara berpakaian. Dalam konteks Indonesia, contoh ekspresi keagamaan melalui pakaian bisa kita lihat pada kelompok perempuan muslim dalam kegiatan sehari-hari. Sebagian perempuan muslim di Indonesia mengenakan jilbab dan niqab di ruang publik untuk mengekspresikan keislamannya.

Beberapa tahun terakhir bermunculan komunitas pengguna niqab di Indonesia, salah satunya Niqab Squad. Seluruh anggota komunitas ini menggunakan niqab pada aktifitas di ruang publik.

Ruang publik adalah ruang atau arena, baik nyata maupun virtual, yang digunakan secara bersama oleh warga masyarakat untuk mengkomunikasikan berbagai ide dan kepentingan, termasuk di dalamnya pandangan dan kepentingan agama. $^{3}$ Seiring dengan pesatnya kemajuan di bidang teknologi dan komunikasi, ruang publik pun berlangsung melalui berbagai media massa, baik cetak, elektronik dan bahkan media internet. ${ }^{4}$

Di Indonesia, Niqab memiliki stigma negatif di tengah kehidupan masyarakat. Pengguna niqab sering kali diasosiasikan dengan pemikiran radikal,

2 Lihat, Tantan Hermansah, Bid'ah Hasanah dalam Pembangunan Ekonomi Kreatif di Industri Fashion Bandung. Dalam, Jurnal Pemberdayaan Masyarakat: Media Pemikiran dan Dakwah Pembangunan. Vol. 3, no. 2 (2019), hal. 265-284, http://ejournal.uinsuka.ac.id/dakwah/jpmi/index

${ }^{3}$ Noorhaidi Hasan dan Irfan Abubakar, Islam di Ruang Publik: Politik Identitas dan Masa Depan Demokrasi di Indonesia, intoleran, hingga terorisme. Apalagi setelah kejadian ledakan bom Surabaya yang dilakukan oleh seorang ibu dan dua anaknya yang menggunakan niqab.

Berbagai respon negatif dari masyarakat kepada pengguna niqab mulai dari tatapan sinis, teriakan, dan penggeledahan tas ketika memasuki ruang-ruang publik seperti mal. ${ }^{5}$

Pemberitaan tentang tindak terorisme seringkali menyudutkan para pengguna cadar. Media masih menggunakan ilustrasi gambar untuk berita terorisme dengan foto wanita bercadar. Hal tersebut mempertebal anggapan bahwa wanita bercadar terafiliasi dengan kelompok teroris.

Hesti Rika dalam karya foto esai yang berjudul Perjuangan Muslimah Bercadar Menghapus Stigma Negatif di cnnindonesia.com mengajak kita melihat kegiatan para wanita muslim yang menggunakan Niqab di ruang publik. Bagaimana mereka naik transportasi umum, berkumpul, bekerja, dan vakansi seperti masyarakat pada umumnya.

Foto esai adalah rangkaian argumen yang menyatakan sudut pandang tertentu dari si fotografer

(Jakarta: Center for the Study of Religion and Culture (CSRC) Universitas Islam Negeri (UIN) Syarif Hidayatullah Jakarta, 2001), h.2.

${ }^{4}$ Noorhaidi Hasan dan Irfan Abubakar, Islam di Ruang Publik: Politik Identitas dan Masa Depan Demokrasi di Indonesia, h.3.

${ }^{5}$ Aditya Widya Putri," 2 Minggu PascaBom Surabaya: Ragam Kisah Perempuan Bernikab," diakses dari https://tirto.id/2minggu-pasca-bom-surabaya-ragam-kisahperempuan-bernikab-cK8L pada 3 juli 2018 pukul 18.46 . 
terhadap suatu isu. ${ }^{6}$ Foto esai juga bisa digunakan sebagai kritik atau respon terhadap situasi tententu.

Karena foto dapat dianalisis, dapat dijabarkan dan dapat memberikan pandangan baru yang bermanfaat bagi masyarakat luas. Seperti yang dikatakan Paul Messaris pada buku Kisah Mata karya Seno Gumira Adjidarma, bahwa,

"Gambar-gambar yang telah dihasilkan manusia termasuk hasil dari fotogarfi dapat dipandang sebagai suatu keberaksaraan visual. Dengan kata lain, gambar tersebut bisa dibaca karena merupakan bagian dari suatu cara berbahasa. Jika dalam berbahasa bisa diandaikan sebagai produk pikiran, sehingga tercipta wacana pengetahuan, maka demikian pula halnya dengan penghadiran gambar-gambar." 7

Dengan demikian dapat dikatakan bahwa foto sama halnya dengan teks atau aksara yang dapat dibahas melalui makna-makna yang terkandung dalam foto tersebut, karena semua yang ada dalam kehidupan kita sebenarnya memiliki makna atau pesan yang ingin disampaikan. ${ }^{8}$

\section{METODE}

Paradigma adalah metode atau cara berpikir yang digunakan dalam peneltian. Dalam penelitian ini digunakan paradigma konstruktivis. Paradigma

6 Taufan Wijaya, Foto Jurnalistik, (Jakarta: PT Gramedia Pustaka Utama, 2014), h.76.

7 Seno Gumira Ajidarma. Kisah Mata, Fotografi Antara Dua Subjek: Perbincangan Tentang Ada, (Yogyakarta: Galang Press, 2002), h.26 konstruktivis memandang realitas merupakan hasil kontruksi sosial yang diciptakan individu. Kebenaran suatu realitas sosial bersifat tidak mutlak, kebenaran berlaku sesuai konteks spesifik yang dinilai relevan oleh pelaku sosial. ${ }^{9}$

Penelitian menggunakan pendekatan kualitatif sebagai metode penelitian yang temuannya dideskripsikan kemudian ditinjau kembali untuk dianalisis dari hasil pengamatan di lapangan. Observasi, wawancara, dokumen pribadi, foto, rekaman, gambar, dan percakapan informal merupakan sumber data kualitatif. ${ }^{10}$ Dengan model pendekatan kualitatif bertujuan untuk menjelaskan temuan dan memahami masalah secara menyeluruh, tetapi sebagaimana cara kerjanya, tidak melakukan generalisasi.

Objek dalam penelitian ini adalah foto berjudul Perjuangan Muslimah Bercadar Menghapus Stigma Negatif yang terbit di website cnnindonesia.com. Penelitian dibatasi dengan memilih lima dari 12 foto yang terbit pada website tersebut.

Sumber data dalam penelitian ini dibagi menjadi 2 kategori yaitu: Pertama, Data Primer atau data yang diperoleh melalui foto yang tampil pada halaman website cnnindonesia.com, dan, Kedua, Data Sekunder atau data yang diperoleh dari hasil wawancara dengan fotografer

8 Seno Gumira Ajidarma, Kisah Mata, Fotografi Antara Dua Subjek: Perbincangan Tentang Ada, h.29.

${ }^{9}$ Burhan Bungin, Konstruksi Sosial Media Massa, (Jakarta: Kencana Prenada Media Grup, 2011) h.11.

10 Emzir, Metodologi Penelitian Kualitatif: Analisis Data, (Jakarta: PT Raja Grafindo Persada, 2010), h.37. 
dan studi kepustakaan yang terkait semiotika dan fotografi untuk mendukung penelitian ini.

Sedangkan proses atau tehnik pengumpulan data dalam studi ini terdiri dari: Pertama, proses dokumentasi yang dilakukan untuk mendapatkan informasi yang berhubungan dengan data-data berupa file foto, dokumen, arsip atau catatan-catatan tentang hal yang berhubungan dengan foto tersebut; dan Kedua, wawancara yang merupakan metode pengumpulan data digunakan untuk memperoleh informasi langsung dari sumbernya. ${ }^{11}$ Dalam penelitian ini wawancara dilakukan melalui tatap muka dengan fotografer.

\section{TINJAUAN TEORI}

\section{Fotografi}

Fotografi merupakan sebuah ilmu tentang melukis dengan cahaya. Kata fotografi berasal dari bahasa Yunani, yaitu photos dan graphein. Photos memiliki arti cahaya sedangkan graphein berarti melukis. Istilah tersebut pertama kali dikemukakan oleh Sir John Herschell seorang ilmuan asal Inggris tahun 1839.12 Foto-foto bisa lebih mudah diingat dibandingkan dengan gambar bergerak karena berupa irisan tipis waktu, bukan waktu yang berjalan (Sontag, 1977). Foto dipercaya sebagai testimoni yang independent, agen diskursus sosial, dan kini mudah

${ }^{11}$ Rachmat Kriyantono, Teknik Praktis Riset Komunikasi, (Jakarta: Kencana Prenada Media Grup, 2012), h.100.

12 Ferry Darmawan, Dunia Dalam Bingkai, (Yogyakarta: Graha Ilmu, 2009), h. 19.

13 Taufan Wijaya, Literasi Visual, (Jakarta: PT Gramedia Pustaka Utama, 2018) h. 1. dibagikan dalam waktu sekejap ke banyak orang. Untuk menjelaskan bagaimana rupa seseorang atau betapa indahnya pantai, sebuah foto mampu menjelaskannya. ${ }^{13}$

Fotografi mulai populer sejak tahun 1901 setelah Kodak Brownie diperkenalkan. ${ }^{14}$ Kemajuan teknologi telah membuat perubahan besar bagi dunia fotografi. Saat ini teknologi digital telah merambah sendi-sendi kehidupan, tidak terkecuali fotografi. Sistem digital yang menjadi main stream fotografi abad ke-21 telah membuat kegiatan memotret dan mencetak foto menjadi demikian mudah dan praktis. Sekali bidik, foto pun langsung jadi, dan hasilnya dapat langsung dilihat di layar monitor. Jika foto belum memuaskan, fotografer dapat dengan mudah menghapusnya, kemudian mengulangi pemotretan lagi, tanpa repot dan tanpa biaya. ${ }^{15}$

2. Foto Jurnalistik

Fotografi Jurnalistik adalah salah satu aliran fotografi yang lebih mengutamakan realita dibandingkan dengan aliran lainnya. Dalam dunia jurnalistik, foto menjadi hal yang paling penting untuk mewakili sebuah pemberitaan atau informasi yang tidak dapat disampaikan hanya dengan sebuah tulisan. ${ }^{16}$

Foto dikategorikan sebagai foto jurnalistik saat foto itu terdapat nilainilai berita yang terkandung di dalamnya,

14 Ferry Darmawan, Dunia Dalam Bingkai, h. 15.

${ }^{15}$ Pitri Ermawati, MEDIA FOTOGRAFI ABAD KE-19: DAGUERREOTYPE, CALOTYPE, DAN COLLODION, (Jurnal Rekam, 2017), h. 127.

16 Asep Saeful Muhtadi, Jurnalistik: Pendekatan Teori dan Praktek, (Jakarta: Logos Wacana IImu, 1999), h. 100. 
foto jurnalistik tidak harus bersifat kekerasan dan hal-hal berat lainnya, jika sebuah foto sudah memiliki nilai berita bagi umum sesederhana apa pun foto tersebut sudah bisa dikategorikan sebagai foto jurnalistik. ${ }^{17}$

Dalam foto jurnalistik, anggapan sebuah gambar lebih bermakna dibandingkan seribu kata tidak berlaku. Karena foto jurnalistik perlu keterangan tertulis atau teks penyerta (caption). Keterangan tersebut mempertemukan foto dengan konteksnya, dan membantu pemahamahan cerita di balik foto. Caption juga mampu menggiring mata pembaca untuk kembali melihat foto. ${ }^{18}$

Di Indonesia, fotografi jurnalistik muncul pada 1841 oleh Juriaan Munich, seorang utusan kementerian kolonial lewat jalan laut di Batavia. Lalu kita mengenal seorang anak Indonesia yang diangkat oleh pasangan Belanda bernama Kassian Cephas yang foto pertamanya diidentifikasi dibuat pada tahun $1875 .{ }^{19}$

\section{Semiotika}

Semiotika berasal dari bahasa Yunani yaitu dari kata semeion yang berarti "tanda". Secara terminologis, semiotika didefinisikan sebagai ilmu yang mempelajari objek-objek, peristiwa-peristiwa dan seluruh kebudayaan sebagai tanda. Van Zoest mengartikan semiotika sebagai "Ilmu tanda" dan segala yang berhubungan dengannya, cara berfungsinya, hubungannya dengan kata lain,

17 Ferry Darmawan, Dunia Dalam Bingkai, h. 165.

18 Taufan Wijaya, Literasi Visual h. 6.

19 Taufan Wijaya, Foto Jurnalistik, h. 7.

20 Umberto Eco, Sebuah Pengantar Menuju Logika Kebudayaan, dalam Serba- pengerimannya dan penerimaannya oleh mereka yang mempergunakannya

$\begin{array}{rrr}\begin{array}{c}\text { Belakangan } \\ \text { kecenderungan }\end{array} \text { untuk } & \text { melihat }\end{array}$ permasalahan komunikasi massa melalui perspektif semiotika. Sementara itu, metode semiotika bermanfaat untuk menjelaskan sejumlah fenomena komunikasi massa, termasuk foto. ${ }^{20}$

Menurut Barthes, semiotika adalah suatu ilmu atau metode analisis untuk mengkaji tanda. Tanda-tanda adalah perangkat yang kita pakai dalam upaya berusaha mencari jalan di dunia ini, di tengah-tengah manusia dan bersama-sama manusia. Barthes menjabarkan bahwa foto itu memuat tanda yang berupa pesan tertunjukkan/denotatif dan pesan terartikan/konotatif.

Barthes menyempurnakan teori semiotik Saussure yang hanya berhenti pada pemaknaan penanda dan petanda saja (denotasi). Barthes mengembangkan dua tingkatan pertandaan (two way of signification), yang memungkinkan untuk dihasilkannya makna yang juga bertingkat-tingkat, yaitu tingkat denotasi dan konotasi. ${ }^{21}$

Seno Gumirah Ajidarma dalam bukunya berjudul Kisah Mata mengatakan:

"Foto adalah suatu pesan yang dibentuk oleh suber emisi, saluran transmisi dan titik resepsi. "Struktur sebuah foto bukanlah sebuah struktur yang terisolasi,

Serbi Semiotika, (Jakarta: PT Gramedia Pustaka Utama), 1996, h. 41.

21 Alex Sobur, Semiotika Komunikasi, (Bandung: Remaja Rosdakarya, 2003), h.69 
karena selalu berada dalam komunikasi dengan struktur lain, yakni teks tertulis, judul, keterangan ,artikel, yang selalu mengiringi foto. Dengan demikian keseluruhannya dibentuk oleh kooperasi dua struktur yang berbeda". 22

Merujuk pada penjelasan di atas, dapat dilihat bahwasannya karya fotografi tidak bisa dilihat sebatas sebuah kenampakan secara objektif, melainkan fotografi memiliki makna yang lebih dari sekedar yang dipaparkan. Sebab melihat dari proses terciptanya foto yang melibatkan sepenuhnya fotografer, maka tidak dapat dipungkiri akan adanya keterlibatan unsur subjektifitas di dalamnya. Sehingga, apabila foto itu merupakan media untuk menyampaikan gagasan, maka gagasan dan upaya untuk bercerita itu sendiri adalah bentuk subjektivitas.

4. Konstruksi Sosial Media Massa

Konstruksi realitas sosial terkenal sejak diperkenalkan oleh Peter L. Berger dan Thomas Luckmann melalui bukunya yang berjudul The Social Construction of Reality: A Treatise in the Sociological of Knowledge (1966). Mereka menggambarkan proses sosial melalui tindakan dan interaksinya, di mana individu menciptakan secara terus

22 Seno Gumira Ajidarma, Kisah Mata, (Yogyakarta: Galang Press, 2002) h. 27.

23 Burhan Bungin, Konstruksi Sosial Media Massa: Kekuatan Pengaruh Media Massa, Iklan Televisi, dan Keputusan Konsumen Serta Kritik Terhadap Peter L. Berger \& Thomas Luckmann, (Jakarta: Kencana, 2011). h. 13.

24 Alex Sobur, Analisis Teks Media: Suatu Pengantar Untuk Analisa Wacana Analisis Semiotik, dan Analisis Framing menerus suatu realitas yang dimiliki dan dialami bersama secara subyektif. ${ }^{23}$

Sebuah realitas sosial tidak berdiri sendiri tanpa kehadiran individu, baik di dalam maupun di luar realitas tersebut. Realitas sosial memiliki makna ketika realitas sosial dikonstruksi dan dimaknai secara subjektif oleh individu lain sehingga memantapkan realitas itu secara subjektif. Individu mengkonstruksi realitas sosial dan mengkonstruksinya dalam dunia realitas, memantapkan realitas itu berdasarkan subjektifitas individu lain dalam institusi sosialnya. ${ }^{24}$

\begin{tabular}{llr}
\multicolumn{1}{c}{ Dalam } & penjelasan & ontologi \\
paradigma & konstruktivis, & realitas \\
merupakan & konstruksi sosial yang
\end{tabular} diciptakan individu. Namun demikian kebenaran suatu realitas sosial bersifat nisbi (relatif), yang berlaku sesuai konteks spesifik yang dinilai relevan oleh perilaku sosial. ${ }^{25}$

Menurut Ibnu Hamad, bahasa merupakan unsur utama dalam konstruksi realitas. Bahasa adalah instrumen pokok untuk menciptakan suatu realitas. Bahasa sebagai alat konseptualitas dan alat narasi. ${ }^{26}$ Ia membagi bahasa menjadi dua yaitu bahasa verbal (tulisan dan lisan) dan non verbal (gambar, foto, grafik, tabel).

(Bandung: PT Remaja Rosdakarya, 2002). h. 90.

25 Burhan Bungin, Sosiologi Komunikasi: Teori Paradigma dan Diskursus Teknologi Komunikasi di Masyarakat, (Jakarta: Kencana, 2008), h. 191.

26 Ibnu Hamad, Agus Sudibyo, Mohamad Qodari, Kabar Kabar Kebencian: Prasangka Agama di Media Massa (Jakarta: ISAI, 2001), h.69. 
Menyiapkan materi konstruksi sosial media massa adalah tugas redaksi media massa. Isu- isu penting setiap hari menjadi fokus media massa, terutama yang menyangkut tiga hal, yaitu kedudukan (takhta), harta, dan perempuan. Selain tiga itu ada juga fokusfokus lain, seperti informasi yang sifatnya menyentuh perasaan banyak orang yaitu persoalan sensitivitas, sensualitas dan kengerian. ${ }^{27}$

5. Jilbab dan Cadar

Jilbab adalah busana muslimah, yaitu suatu pakaian yang tidak ketat atau longgar dengan ukuran lebih besar yang menutupi tubuh perempuan, kecuali muka dan telapak tangan. ${ }^{28}$ Jilbab bukan sekadar pakaian, akan tetapi mengandung kehormatan, kemuliaan, dan keislaman seseorang. ${ }^{29}$

Menurut Nasaruddin Umar, ada enam model pakaian wanita muslimah pada masa Rasulullah SAW. Pertama burqu', berupa kain transparan atau perhiasan perak yang menutupi bagian muka kecuali dua bola mata. Kedua niqab, berupa kain halus yang menutupi bagian hidung dan mulut. Ketiga miqna'an, berupa kain kecil yang menutupi kepala. Keempat qina', yaitu kain penutup yang lebih lebar dari miqna'an. Kelima nishaf yaitu kain penutup yang lebih Panjang atau selendang. Sedangkan yang terakhir ialah khimar penutup kepala namun tidak

27 Burhan Bungin, Konstruksi Sosial Media Massa: Kekuatan Pengaruh Media Massa, Iklan Televisi, dan Keputusan Konsumen Serta Kritik Terhadap Peter L. Berger \& Thomas Luckmann. h. 196.

28 Sulaiman Mulya dan Assad Ali Mochammad, Berhijab Seutuhnya, (Jakarta: Firdauss Presindo, 2015), h. 9.

${ }^{29}$ Dr. Fuad Mohd. Fahruddin, Aurat dan Jilbab Dalam Pandangan Mata Islam, menjangkau bagian dada, sehingga bagian leher maupun dada tetap terlihat. ${ }^{30}$

Cadar adalah kain penutup kepala atau muka bagi perempuan. Niqab adalah istilah syar'i untuk cadar yaitu sejenis kain yang digunakan untuk menutupi wajah. Niqab dikenakan oleh sebagian kaum perempuan Muslimah sebagai kesatuan dengan jilbab (hijab). Niqab menurut bahasa Arab, adalah penutup wajah yang menampakkan lingkar kedua mata. Menurut Ibnu Sirin, niqab yang menampakkan lingkar kedua mata adalah sesuatu yang muhdats (baru muncul kemudian). ${ }^{31}$

Cadar merupakan versi lanjutan dari jilbab. Pengguna cadar menambahkan penutup wajah sehingga hanya terlihat mata mereka saja, bahkan telapak tangan pun harus ditutupi. Jika berjilbab mensyaratkan pula penggunaan baju panjang, maka bercadar diikuti kebiasaan penggunaan gamis rok panjang dan lebar, dan biasanya seluruh aksesoris berwarna hitam atau berwarna gelap. ${ }^{32}$

Jika jilbab bisa masuk ke dalam budaya lokal, maka cadar belum mampu menembus media massa, tempat produksi budaya-budaya populer. Justru sampai saat ini, media menampilkan cadar sebagai bagian dari indikator identitas istri teroris. Cadar belum

(Jakarta: CV. Pedoman IImu Jaya, 1984), h.35.

30 Nasaruddin Umar, Fikih Wanita Untuk Semua, (Jakarta: Serambi IImu Semesta, 2010), h. 22.

31 Sufyan Bin Fuad Baswedan, Samudera Hikmah Di Balik Jilbab Muslimah, (Jakarta:Pustaka Al-Inabah, 2013), h.40.

32 Lintang Ratri, Cadar, Media, Dan Identitas Muslim, (Jurnal Undip: 2011), h. 33 
pernah ditampilkan di media secara positif, sampai hari ini cadar lekat dengan stigma istri teroris dan simbol Islam garis keras, dimana di negara yang plural, fanatisme sempit dilihat sebagai ancaman.

\section{PEMBAHASAN}

Kajian ini menginterpretasikan lima foto karya Hesti Rika yang sudah ditayangkan pada web. Cnnindonesia.com. Kelima foto tersebut adalah:

\section{Gambar 1}

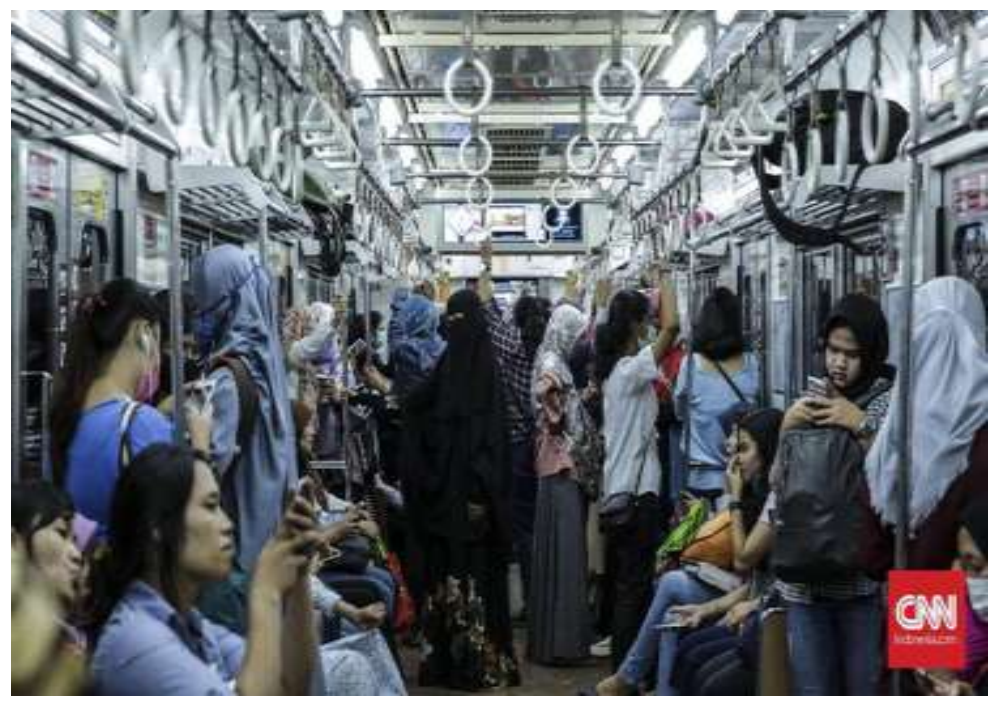

Foto ini memperlihatkan suasana di dalam gerbong transportasi publik jenis Kereta Rel Listrik (KRL). Terlihat seorang pengguna cadar bernama $\mathrm{Sul}^{33}$ berada di antara penumpang lainnya. Sul sedang berdiri memegang tiang penyangga di dalam kereta. Ia menggunakan pakaian berwarna hitam. Dalam foto ini juga terlihat ramainya penumpang lain yang sedang asik dengan kegiatannya masing-masing. Terlihat bahwa tidak ada interaksi dari pengguna cadar kepada penumpang yang lain.

Secara teknis, dalam foto 1 ini tidak ditemukan adanya manipulasi gambar secara artifisial. Terlihat pose

33 Wawancara langsung dengan Hesti Rika pada 3 Oktober 2019 di Kantor seorang pengguna cadar yang sedang berdiri dengan tangan memegang tiang di dalam gerbong kereta. Gestur subjek dalam foto ini terlihat nyaman, tidak ada sikap yang menunjukan bahwa ia merasa terintimidasi dengan menggunakan cadar di ruang publik.

Foto ini diambil dengan teknik eye level, menurut ST Sunardi dalam buku Semiotika Negativa, teknik ini dapat memberikan kesan sejajar atau setara. Dalam konteks makna dalam foto ini, pengambilan teknik ini seolah ingin menjelaskan pada pelihat foto bahwa pengguna cadar sama seperti masyarakat pada umumnya.

cnnindonesia.com, Gedung Trans Media Lt.3A, Mampang Prapatan, Jakarta Selatan. 
Di dalam foto terdapat teks yang tertulis:

"Pengguna cadar kerap dicap sebagai kelompok radikal. Namun itu tidak menyurutkan sejumlah muslimah mempopulerkan cadar dalam kegiatan sehari-hari."

Pada teks tersebut jelas sekali fotografer ingin menceritakan bahwa objek dalam fotonya adalah seorang yang kerap kali dicap radikal di Indonesia.

Jika melihat foto tersebut, mitos perempuan bercadar sebagai sosok yang membatasi diri pada lingkungan sekitarnya tidak sepenuhnya benar. Selama ini, mitos tersebut hanya stigma yang terbangun oleh media dan masyarakat.

Secara denotatif, gambar 1 ini menunjukkan bahwa subyek yang memakai cadar bisa membaur dengan masyarakat lainnya. Penampilan mereka yang terkesan tertutup apalagi dengan warna busana yang dominan berwarna gelap, tidak membuatnya terasa berjarak.
Dari sisi subyek pun, terlihat bahwa dia tidak merasa kesulitan untuk membaur pada transportasi publik.

Sedangkan secara konotatif, foto ini memberikan pesan kepada kita bahwa stereotipe atas mereka itu tidak terbukti. Mereka hanya subyek yang berusaha menjalankan keyakinannya. Mereka seperti kelompok masyarakat lainnya. Jika penampilannya terlihat berbeda dengan kebanyakan, kita juga banyak menemukan orang-orang yang berpenampilan berbeda, seperti bertato dan sebagainya.

Dari aspek mitos, foto ini menunjukkan bahwa pandangan yang diskriminatif atas kelompok ini jelas tidak masuk akal. Berbusana bukan hanya sekedar menutupi tubuh dan agar pantas dilihat orang. Sebab dalam perspektif pelaku, berbusana adalah upaya menjalankan dan mengimplementasikan keyakinan yang nantinya akan berhubungan dengan persoalan hidup setelah mati.

Gambar 2

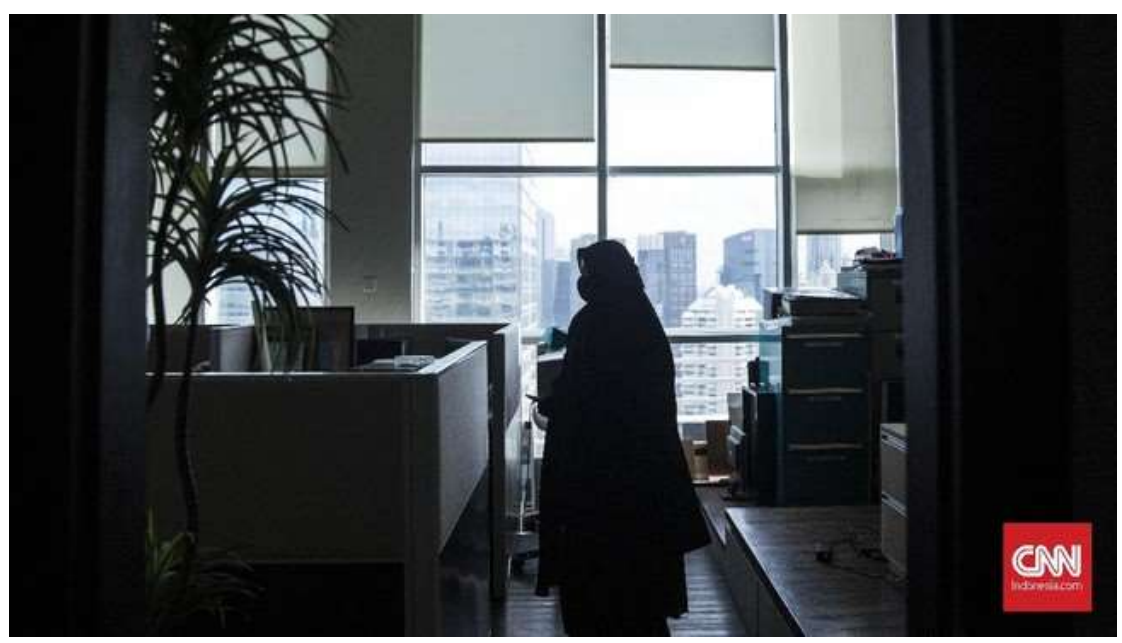


Dalam foto ini terlihat siluet seorang wanita pengguna cadar sedang berada di dalam kantor. Diketahui, pengguna cadar ini bernama Sulis yang bekerja disebuah kantor jasa arsitek di daerah Kuningan, Jakarta. ${ }^{34}$ Kantor tempat Sulis bekerja tidak memperbolehkan karyawannya mengenakan cadar. Untuk itu, Sulis mengganti cadarnya dengan masker saat berada di kantornya.

Dalam foto ini terlihat gestur siluet seorang wanita pengguna cadar sedang berdiri dan menengok ke arah kiri. Fotografer menempatkan pengguna cadar sebagai point of interest dalam foto ini.

Teknik siluet adalah teknik fotografi yang pencahayaan pada background lebih terang dari pencahayaan pada objek yang difoto. Foto ini diambil dengan sudut pandang eye level. Menurut M. Budyatna dalam bukunya berjudul Jurnalistik, Teori dan Praktik mengatakan bahwa sebuah foto yang diambil dengan Teknik pencahayaan low key ${ }^{35}$ menggambarkan suram dan muram.

Dalam wawancara dengan fotografer diketahui bahwa Sulis (subjek dalam foto ini) dilarang menggunakan cadar oleh perusahaan tempat ia bekerja. Namun, agar tetap bekerja di perusahaan tersebut ia mengganti cadarnya dengan sebuah masker untuk menutupi auratnya.

${ }^{34}$ Wawancara langsung dengan Hesti Rika pada 3 Oktober 2019 di Kantor cnnindonesia.com, Gedung Trans Media Lt.3A, Mampang Prapatan, Jakarta Selatan.
Di dalam foto terdapat teks yang tertulis:

"Bercadar bukan salah satu penghalang Muslimah tidak produktif berkarya dan berusaha. Namun, tidak semua Lembaga memperbolehkan. Hal itu yang dirasakan Sulis. Sulis tetap menutup aurat wajahnya dengan masker."

Teks dalam foto ini menceritakan bagaimana tantangan yang dihadapi oleh pengguna cadar dalam dunia kerja. Ia dipaksa memilih antara keyakinan atau tetap menjadi produktif.

Dalam konteks Indonesia di masa orde baru, sempat ada pelarangan penggunaan jilbab di sekolah dan ruang kerja. Baru-baru ini ada wacana pelarangan cadar oleh Menteri Agama di Instansi Pemerintahan. Pelarangan tersebut dilakukan dengan alasan keamanan. Hingga saat ini, cadar masih dianggap ancaman. Pelarangan cadar di dunia kerja selalu menimbulkan polemik. Pengguna cadar selalu dihadapkan dengan peraturan perusahaan tempat ia bekerja dengan keyakinan dan hak asasi yang dimilikinya.

Secara mitos foto ini ingin memberikan makna bahwa mereka yang selama ini dianggap "mencurigakan" bisa membaur dalam situasi yang tidak pernah terbayangkan sebelumnya, yakni dunia kerja. Selain itu, pelarangan atas perilaku bercadar ternyata tidak pernah

35 Low key adalah fotografi yang bernuasna gelap, cocok untuk memberikan nuansa misterius dalam foto. 
menyurutkan pelakunya untuk melakukan hal tersebut meski dengan menyiasatinya menggunakan maskes yang umum dipergunakan banyak orang.

\section{Gambar 3}

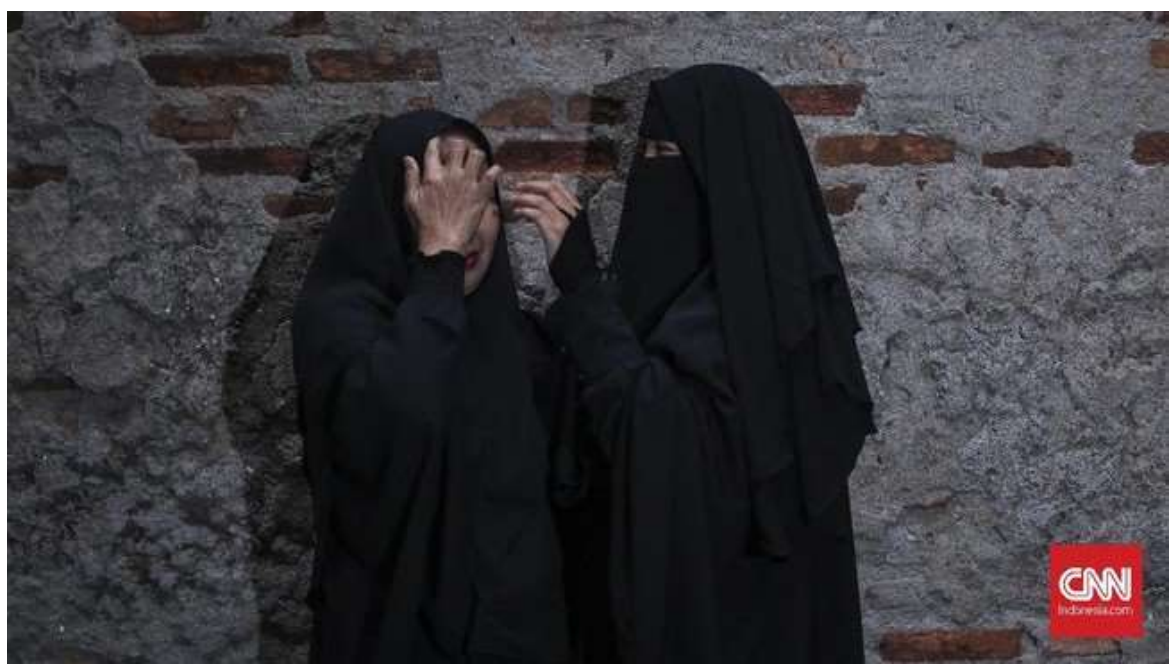

Dalam foto ini terlihat dua perempuan yang mengenakan pakaian hitam berjilbab, salah satunya mengenakan cadar. Diketahui perempuan yang mengenakan cadar bernama Dewi. Dalam foto tersebut, Dewi sedang membetulkan jilbab perempuan yang tidak bercadar disampingnya.

Perempuan yang tidak mengenakan cadar adalah Ibu dari Dewi.

Dalam foto ini terlihat gesture Dewi (kanan) sedang membetulkan jilbab ibunya (kiri). Makna konotasi dari gesture ini seakan akan dewi sedang membetulkan agama sang ibu yang belum mengenakan cadar. Hal tersebut terkonfirmasi dalam wawancara penulis dengan fotografer bahwa sebelumnya sang ibu tidak mendukung Dewi untuk mengenakan cadar. Setelah kejadian ini, sang ibu ikut pengajian dan bercadar seperti Dewi. ${ }^{36}$

36 Wawancara langsung dengan Hesti Rika pada 3 Oktober 2019 di Kantor
Foto ini diambil dalam keadaan yang minim cahaya. Hal tersebut terlihat dari penggunaan flash eksternal dalam pengambilan foto ini.

Pada foto ini terlihat fotografer menggunakan teknik pengambilan gambar medium shot. Teknik tersebut memiliki makna konotasi hubungan yang sangat dekat antar kedua objek. Bisa dilihat dari hampir setengah frame foto tersebut diisi oleh kedua objek. Dalam bukunya yang berjudul Jurnalistik, Teori dan Praktik, M. Budyatna mengatakan bahwa medium shot juga menandakan kedekatan antara fotografer dan objek foto.

Di dalam foto terdapat teks yang tertulis:

"Keputusan menggunakan cadar tidak mudah. Bahkan terkadang ditentang keluarga. Dewi mengakui hal itu, tetapi lambat laun keluarganya menerima."

cnnindonesia.com, Gedung Trans Media Lt.3A, Mampang Prapatan, Jakarta Selatan. 
Sesuai teks di atas, terjadi konflik antara Dewi dan ibunya. Dewi sempat ditentang oleh keluarganya ketika menggunakan cadar. Tetapi lambat laun justru Dewi berhasil meyakinkan ibunya dan mengajak ibunya untuk ikut menggunakan cadar.

Dalam masyarakat penggunaan cadar masih dilabeli stereotip negatif, keputusan mengenakan cadar pada perempuan muslim bukanlah sebuah keputusan yang mudah. Selain itu, kewajiban dalam menutup aurat yang umum diterima mayoritas muslim di Indoensia adalah jilbab. Cadar masih merupakan bentuk busana yang jarang digunakan. Karena itu, seorang perempuan muslim yang mengenakan cadar secara alamiah menjadi berbeda dan tergolong dalam sekelompok kecil minoritas perempuan muslim. ${ }^{37}$

Menggunakan cadar tidak hanya sekedar konsep perlindungan perempuan dalam AlQuran dan Hadist, tapi juga budaya takwa yang diimplementasikan dalam kehidupan sehari-hari. Dengan menggunakan cadar, para pengguna cadar merasa telah melakukan peningkatan keimanan terhadap Allah SWT. ${ }^{38}$

\section{Gambar 4}

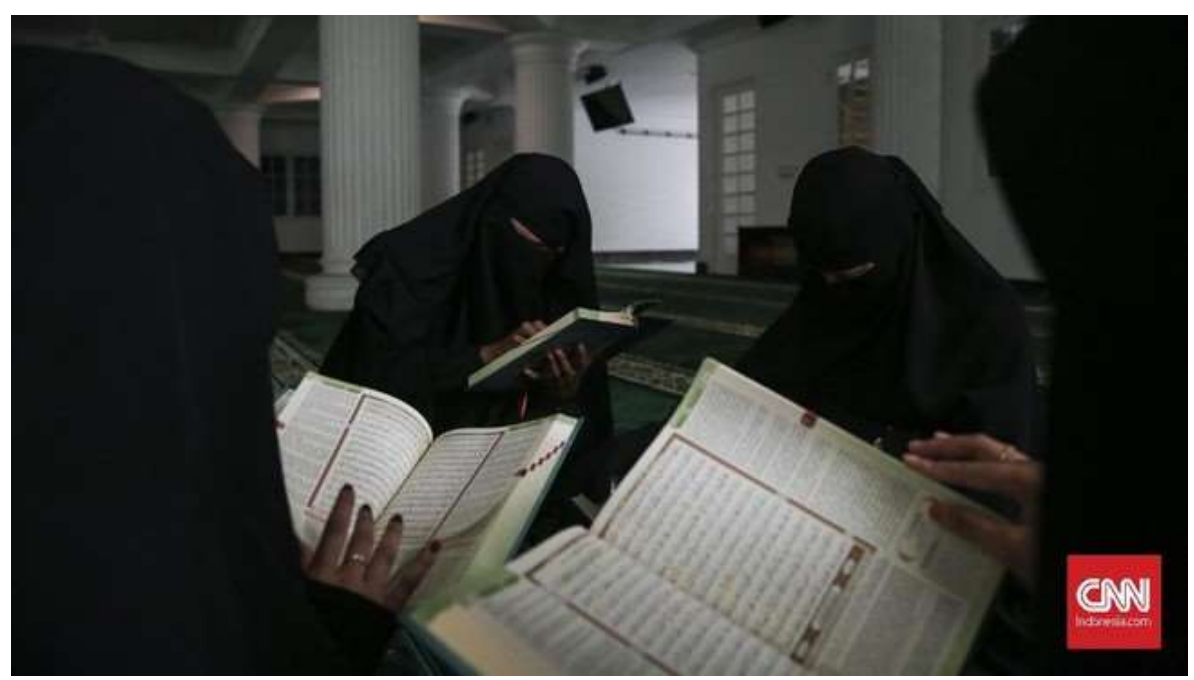

Dalam foto ini terlihat empat pengguna cadar sedang memegang AlQuran. Mereka sedang melakukan pengajian bersama di masjid di wilayah Sunter. ${ }^{39}$

37 Alif Fathur Rahman dan Muhammad Syafiq, Motivasi, Stigma, Coping Stigma pada Perempuan Bercadar, (Jurnal Psikologi Teori dan Terapan Vol 7: 2017), h. 105.

38 Lintang Ratri, Cadar, Media, dan Identitas Perempuan Muslim, hal 33.
Dalam foto ini terlihat keempat pengguna cadar dengan gesture menunduk memperhatikan ke arah AlQur'an. Dapat dipastikan mereka sedang

39 Wawancara langsung dengan Hesti Rika pada 3 Oktober 2019 di Kantor cnnindonesia.com, Gedung Trans Media Lt.3A, Mampang Prapatan, Jakarta Selatan. 
Khusyuk mempelajari apa yang ada di dalam kitab suci tersebut.

Foto ini diambil dengan lensa wide angle. Bisa dilihat dengan jarak pengambilan sedekat itu, fotografer masih bisa menangkap keseluruhan objek. Jika dianalisa menggunakan teknik rule of third, letak Al-Qur'an yang dipegang oleh wanita paling kiri berada tepat pada titik persinggungan garis imajiner dalam teknik tersebut. Sehingga teknik ini menarik pembaca untuk langsung melihat kearah Al-Qur'an tersebut.

Di dalam foto tersebut terdapat teks yang tertulis:

"Ada kekhawatiran muslimah bercadar berubah menjadi pribadi yang tertutup. Sesama mereka pun kerap berkumpul saling bertukar pikiran, pengalaman, dan memperluas lingkar pertemanan."
Jika membaca teks ini, fotografer seakan akan ingin mengatakan perempuan yang bercadar akan menjadi individu yang tertutup. Namun pada kalimat kedua dijelaskan jika perempuan bercadar masih bisa berkumpul dan membangun relasi baru dengan komunitasnya.

$\begin{array}{ccc}\text { Seorang } & \text { wanita yang } & \text { baru } \\ \text { menggunakan } & \text { cadar } & \text { selalu }\end{array}$
dikhawatirkan akan masuk komunitaskomunitas pengajian yang kajiannya berkaitan dengan nilai-nilai radikalisme dan ekstrimisme. Di Indonesia stereotip terhadap pengajian yang diisi oleh pengguna cadar akan menjurus kepada tindakan terorisme. Seperti yang terjadi pada saat kejadian bom bunuh diri di Surabaya dan Sidoarjo 2018 silam. Banyak pemberitaan media massa yang langsung menyoroti kegiatan pengajian yang dilakukan oleh pelaku bom bunuh diri tersebut.

\section{Gambar 5}

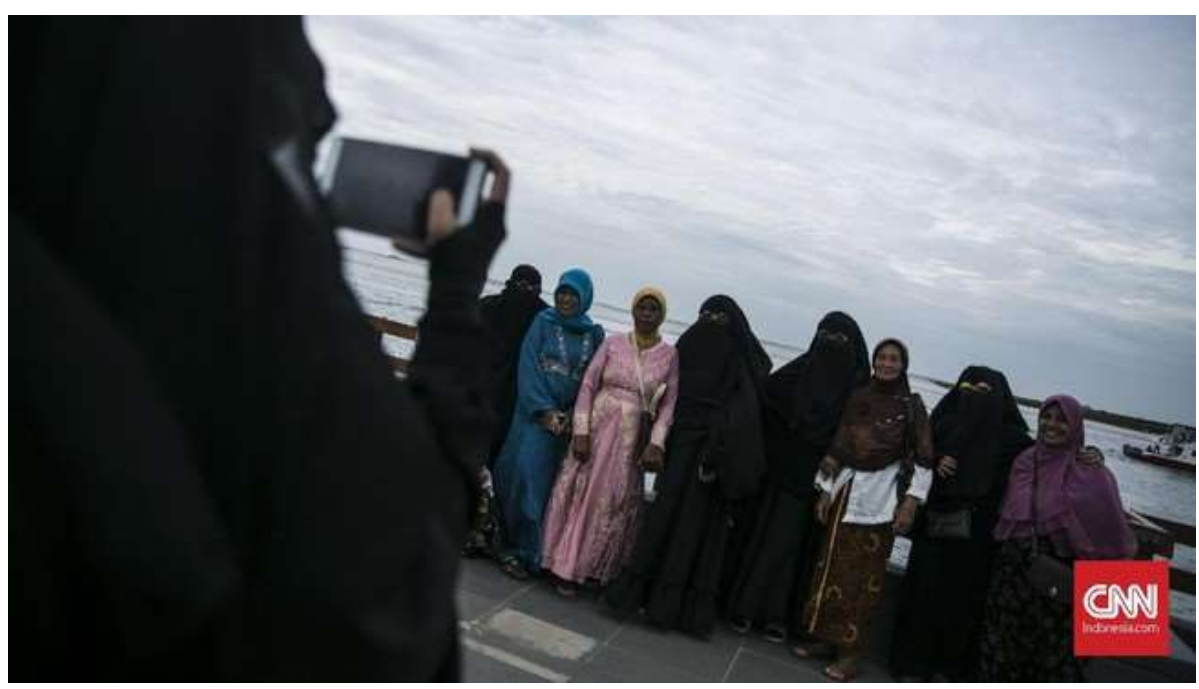

Dalam foto ini terlihat empat pengguna cadar sedang berfoto bersama 
sekelompok ibu-ibu. Dari wawancara dengan fotografer diketahui lokasi ini berada di Ancol. Berikut kutipan wawancara dengan fotografer:

"iya iya, kan ibu ibunya ngeliatin gitu kan, terus disapa sama Sul, pertamanya emang aku liat si Ibu itu takut kan, terus malah disamperin, dideketin, ngobrol. Mereka emang gitu sih kalo ada yang ngeliatinnya gaenak malah disapa, gitu sih. Setelah itu si Ibunya minta foto."

Dalam foto ini terlihat gesture dari seluruh objek yang ada dalam foto sangat cair. Tidak terlihat adanya sekat antara pengguna cadar dengan ibu-ibu tersebut, bisa dilihat dari gesture merangkul yang dilakukan oleh seorang pengguna cadar kepada salah satu ibu di gambar.

Foto ini diambil dengan teknik long shot dengan maksud memperlihatkan semua objek yang ada di lokasi. Makna konotasi dari teknik ini adalah menghubungkan subjek dengan konteks. Konteks dalam hal ini ialah bagaimana pengguna berinteraksi dengan masyarakat di luar komunitasnya. Fotografer berusaha menangkap kehangatan antara komunitas pengguna cadar dengan kelompok masyarakat di luar komunitasnya.

40 Lintang Ratri, Cadar, Media, dan Identitas Perempuan Muslim, hal 33.
Di dalam foto ini terdapat teks yang tertulis:

"Sekelompok wanita bercadar berfoto bersama dengan masyarakat. Mereka ingin mengubah pandangan negatif dengan lebih terbuka kepada masyarakat."

Cadar masih barang asing yang menakutkan. Hal ini didukung stigmastigma yang dikeluarkan media, diantaranya "istri teroris", "islam garis keras", "islam fanatik". Eksklusivitas dan ketertutupan komunitas cadar juga menghambat proses sosialisasi. Belum lagi masyarakat Indonesia yang serba ingin tahu, dari pola masyarakat kolektif, melihat hal-hal yang serba tertutup membuat mereka enggan untuk berinteraksi lebih jauh. Apa yang menjadi opini masyarakat adalah cadar belum menjadi budaya muslim Indonesia. ${ }^{40}$

Dilihat dari foto dan tulisan dalam foto ini stigma pengguna cadar sebagai individu yang eksklusif seakan terbantahkan. Dalam foto ini pengguna cadar pun berinteraksi dengan percaya diri tanpa rasa canggung dengan masyarakat di luar komunitasnya.

\section{Penutup}

Setelah melakukan analisis dari data temuan dan pembahasan terhadap foto berjudul Perjuangan Muslimah Bercadar Menghapus Stigma Negatif karya Hesti Rika yang diterbitkan cnnindonesia.com. Maka dapat 
disimpulkan bahwa foto ini bercerita tentang kehidupan sehari-hari para wanita pengguna cadar baik kehidupan pribadi dan kelompok. Setiap foto yang menggambarkan aktivitas wanita bercadar mulai dari naik angkutan umum, rekreasi ke pantai, mengaji hingga hubungan antara wanita pengguna cadar dan ibunya, menggambarkan realitas kehidupan sehari-hari masyarakat pada umumnya. Hanya saja, yang menjadi subyek riset ini adalah wanita bercadar.

Selain itu, dapat disimpulkan makna yang terkandung dalam sebuah foto tidak bisa dimaknai hanya sebatas apa yang terlihat pada foto. Pemaknaannya melibatkan pengetahuan dari pelihat foto. Oleh karena itu makna yang dipahami antara fotografer dan dan orang yang melihat foto bisa jadi tidak sama. Pada rangkaian foto di atas memiliki beragam makna konotasi. Seperti yang terdapat pada foto pertama menggambarkan kesetaraan antara wanita bercadar dengan wanita lainnya. Lalu pada foto kedua, terdapat kesan suram dan muram pada foto. Keadaan suram yang dimaksud mungkin dalam konteks situasi personal dari subjek foto yang mendapat larangan memakai cadar di tempat ia bekerja. Kemudian jika melihat pada foto kelima, ditemukan makna konotasi yaitu inklusivitas wanita bercadar yang terlihat dari kehangatan antara wanita bercadar dengan masyarakat yang ada di luar kelompoknya. Hal itu dibuktikan dari gestur seorang pengguna cadar yang berpose merangkul seorang ibu.

Tahap mitos adalah kelanjutan dari tahapan-tahapan sebelumnya, yaitu tahap denotasi dan konotasi. Mitos merupakan gambaran yang telah disepakati oleh sebagian atau sekelompok masyarakat yang mempercayainya. Dengan kata lain mitos lahir karena adanya pesan konotasi yang dipercaya oleh banyak orang dalam suatu wilayah atau budaya tertentu. Dalam rangkaian foto Perjuangan Muslimah Bercadar Menghapus Stigma Negati" ini mengandung banyak makna mitos. Seperti anggapan bahwa seorang pengguna cadar sudah pasti memiliki kepribadian yang tertutup dan tidak mau bersosialisasi dengan orang lain. Lalu ada juga anggapan bahwa pengguna cadar selalu berafiliasi dengan kelompok teroris atau perilakunya menjurus kepada tindak terorisme. Kemudian mitos tentang penggunaan cadar otomatis menunjukan bahwa tingkat ketakwaannya lebih tinggi dari yang tidak menggunakan cadar.

Dalam konteks yang lebih luas, studi ini telah membuktikan bahwa pandangan-pandangan tidak obyektif pada satu entitas sesungguhnya konstruksi yang dibuat dan direkayasa. Dibutuhkan keberanian besar untuk mendegradasi realitas ini agar ke depan, kita mendapatkan dunia yang lebih besar untuk condong pada keadilan. 


\section{DAFTAR PUSTAKA}

Abubakar, N. H. (2001). Islam Di Ruang Publik: Politik Identitas dan Masa Depan Demokrasi Indonesia. Jakarta: Center for Study of Religion and Culture (CSRC) Universitas Islam Negeri (UIN) Syarif Hidayatullah.

Ajidarma, S. G. (2002). Kisah Mata, Fotografi Antara Dua Subjek: Perbincangan Tentang Ada. Yogyakarta: Galang Press.

Baswedan, S. B. (2013). Samudera Hikmah Dibalik Jilbab Muslimah. Jakarta: Pustaka Al-Inabah.

Bungin, B. (2008). Sosiologi Komunikasi: Teori Paradigma dan Diskursus Teknologi Komunikasi di Masyarakat. Jakarta: Kencana.

Bungin, B. (2011). Konstruksi Sosial Media Massa. Jakarta: Kencana Prenada Grup.

Buwaizhi, Rini Iswari, Asma Luthfi. Ekspresi Identitas Keacehan Dalam Interaksi Sosial Di Tengah Lingkungan Non-Syariat Islam (Studi Kasus pada Komunitas Ikatan Pelajar Aceh Semarang). http://journal.unnes. ac.id/sju/index.php/solidarity.

Darmawan, F. (2009). Dunia Dalam Bingkai. Yogyakarta: Graha Ilmu.

Eco, U. (1996). Sebuah Pengantar Menuju Logika Kebudayaan, dalam SerbaSerbi Semiotika. Jakarta: Gramedia Pustaka Utama.
Emzir. (2010). Metodologi Penelitian Kualitatif Analisis Data. Jakarta: Raja Grafindo Persada.

Ermawati, P. (2017). MEDIA FOTOGRAFI ABAD KE-19: DAGUERREOTYPE, CALOTYPE, DAN COLLODION. Jurnal Rekam, 127.

Fahruddin, D. F. (1984). Aurat dan Jilbab Dalam Pandangan Mata Islam. Jakarta: Pedoman Ilmu Jaya.

Hermansah, Tantan. Bid'ah Hasanah dalam Pembangunan Ekonomi Kreatif di Industri Fashion Bandung. Dalam, Jurnal Pemberdayaan Masyarakat: Media Pemikiran dan Dakwah Pembangunan. Vol. 3, no. 2 (2019), hal. 265-284, http://ejournal.uinsuka.ac.id/dakwah/jpmi/index

Ibnu Hamad, A. S. (2001). Kabar Kabar Kebencian: Prasangka Agama di Media Massa. Jakarta: ISAI.

Kriyantono, R. (2012). Teknik Praktis Riset Komunikasi. Jakarta: Kencana Prenada Media Grup.

Mochammad, S. M. (2015). Berhijab Seutuhnya. Jakarta: Firdauss Presindo.

Muhtadi, A. S. (1999). Jurnalistik: Pendekatan Teori dan Praktek. Jakarta: Logos Wacana Ilmu.

Putri, A. W. (2018, Mei 26). Tirto. Retrieved from Tirto.id: https://tirto.id/2-minggu-pascabom-surabaya-ragam-kisahperempuan-bernikab-cK8L 
Ratri, L. (2011). Cadar, Media, Dan Identitas Muslim. Jurnal Undip, 33.

Sobur, A. (2002). Analisis Teks Media Suatu Pengantar Untuk Analisa Wacana Analisis Semiotik dan Analisis Framing. Bandung: Remaja Rosdakarya.

Sobur, A. (2003). Semiotika Komunikasi. Bandung: Remaja Rosdakarya.

Syafiq, A. F. (2017). Motivasi, Stigma, Coping Stigma pada Perempuan Bercadar. Jurnal Psikologi Teori dan Terapan Vol: 7, 105.

Sutopo. Oki Rahadianto Beragam Islam, Beragam Ekspresi: Islam Indonesia dalam Praktik. MASYARAKAT, Jurnal Sosiologi, Vol. 15, No. 2, Juli 2010: 85-97.

Umar, N. (2010). Fikih Wanita Untuk Semua. Jakarta: Serambi Ilmu Semesta.

Wijaya, T. (2014). Foto Jurnalistik. Jakarta: Gramedia Pustaka Utama.

Wijaya, T. (2018). Literasi Visual. Jakarta: Gramedia Pustaka Utama. 